\title{
Preferential production of G-CSF by a protein-like Lactobacillus rhamnosus GR-1 secretory factor through activating TLR2- dependent signaling events without activation of JNKs
}

\author{
Shahab Meshkibaf ${ }^{1,2}$, Jörg Fritz ${ }^{3}$, Marcelo Gottschalk ${ }^{4}$ and Sung Ouk Kim ${ }^{1,2^{*}}$
}

\begin{abstract}
Background: Different species and strains of probiotic bacteria confer distinct immunological responses on immune cells. Lactobacillus rhamnosus GR-1 (GR-1) is a probiotic bacterial strain found in both the intestinal and urogenital tracts, and has immunomodulatory effects on several cell types including macrophages. However, detailed immunological responses and the signaling mechanism involved in the response are largely unknown.

Results: We examined the production of GR-1-induced cytokines/chemokines and signaling events in macrophages. Among 84 cytokines and chemokines examined, GR-1 discretely induced granulocyte colony-stimulating factor (G-CSF) mRNA at highest levels (>60-fold) without inducing other cytokines such as IL-1a, IL-1 $\beta, I L-6$ and TNF- $a$ ( $<5$-fold). The toll-like receptor (TLR) 2/6-agonist PAM $\mathrm{CSK}_{4}$, TLR2/1-agonist PAM $\mathrm{CSK}_{4}$ and TLR4-agonist lipopolysaccharide induced all of these inflammatory cytokines at high levels ( $>50$-fold). The TLR2 ligand lipoteichoic acid activated all mitogen-activated kinases, Akt and NF-kB; whereas, GR-1 selectively activated extracellular regulated kinases and p38, NF-KB and Akt, but not c-Jun N-terminal kinases (JNKs) in a TLR2-dependent manner. Using specific inhibitors, we demonstrated that lack of JNKs activation by GR-1 caused inefficient production of pro-inflammatory cytokines but not G-CSF production. A secreted heat-labile protein-like molecule, 30-100 kDa in size, induced the preferential production of G-CSF.
\end{abstract}

Conclusion: This study elucidated unique signaling events triggered by GR-1, resulting in selective production of the immunomodulatory cytokine G-CSF in macrophages.

Keywords: Lactobacillus rhamnosus GR-1, G-CSF, Macrophage, TLR2, NF-kB, ERKs, Akt

\section{Background}

Microorganisms induce diverse immune responses, which can be harmful or beneficial to the host. Unlike pathogenic microbes, probiotics are microorganisms usually isolated from fermented food or healthy individuals, and confer a health benefit to the host when administered in

\footnotetext{
* Correspondence: sung.kim@schulich.uwo.ca

'Department of Microbiology and Immunology and Infectious Diseases Research Group, Siebens-Drake Research Institute, Western University, London, ON N6G 2 V4, Canada

${ }^{2}$ Center for Human Immunology, Western University, London, ON N6G 2 V4, Canada

Full list of author information is available at the end of the article
}

adequate amounts $[1,2]$. Among various probiotic bacteria, Lactobacillus, a Gram-positive facultative anaerobic bacterium, is a common constituent of the indigenous microbiota in the human intestinal and urogenital tracts $[3,4]$, and have been used as probiotics for preventing or treating infectious and inflammatory diseases $[5,6]$. However, different Lactobacillus species and strains elicit strikingly different immune responses in a variety of immune cells and experimental systems [7-10]. L. rhamnosus GG (LGG) is a well-studied strain that can induce inflammatory responses in dendritic cells (DCs) and aggravate dextran sulfate sodium-induced acute colitis in mice [11, 12]. 
In contrast, LGG was shown to have anti-inflammatory effects on mouse and human macrophage cell lines [7, 13], and renders beneficial effects on chronic dextran sulfate sodium-induced mouse colitis and pouchitis in human $[14,15]$. Two soluble factors from LGG, referred to as p75 and $\mathrm{p} 40$, prevent apoptotic cell death of intestinal epithelial cells, through activating the epithelial growth factor receptor [16, 17]. These factors ameliorate dextran sulfate sodium-induced acute colitis, as well as oxazolone and trinitrobenzenesulfonic acid-induced chronic colitis in mice [18]. GR-1, which is closely related to LGG, colonizes both the intestinal and urogenital tracts after oral supplements [19-21]. In human placental trophoblast cells, GR-1 increases IL-10 and G-CSF production, but suppresses TNF- $\alpha$ production $[22,23]$. In the human bladder carcinoma cell line T24, GR-1 alone has little stimulatory effects in producing inflammatory cytokines and chemokines; however, potentiated $E$. coli-induced activation of the nuclear factor kappa-light-chain-enhancer of activated B cells (NF-kB) and production of inflammatory cytokines [24, 25]. GR-1 can also render anti-inflammatory effects on macrophages [26, 27] and dendritic cells [28], and promotes the generation of regulatory T cells in humans [29]. To date, detailed immune responses and signaling mechanisms elicited by GR-1 remain largely unknown.

Macrophages are key innate immune cells, orchestrating immune responses through releasing various proand anti-inflammatory cytokines. These cells are highly populated in the intestinal and urogenital tracts, interacting directly with microorganisms that have crossed the epithelial barrier [30, 31]. Macrophages detect microbe-associated molecular patterns (MAMPs) thorough pattern recognition receptors (PRRs) such as toll-like receptors (TLRs) and nucleotide-binding oligomerization domain (NOD)-like receptors. Although probiotics harbor MAMPs, they rarely cause infections and inflammatory diseases, but discretely modulate host immune responses through inducing distinct production profiles of cytokines and chemokines [7-10,32]. Although details remain to be elucidated, several strains of probiotic bacteria have been shown to have immunomodulatory activities through selectively activating PRRs or regulating signaling cascades initiated by PRRs. For example, cell wall components such as peptidoglycan [33] and lipoteichoic acid (LTA) [34-36], cell wall associated polysaccharide [37], S layer protein A [38], bacteriocins $[39,40]$, pilus [41] and histamine [42, 43] have each been shown to modulate pro-inflammatory responses in macrophages and dendritic cells through activating specific or unidentified receptors. Also, several probiotic bacteria were shown to suppress inflammatory cytokine expression or promote anti-inflammatory cytokines by inhibiting activation of NF-kB [35, 44, 45], JNKs [46] and extracellular regulated protein kinases (ERKs) $[35,45]$. The present study examined cytokines produced, signaling cascades activated, and bacterial factor(s) released by GR-1 in macrophages. We found that a proteinlike factor released by GR-1 specifically and potently induced the immunomodulatory G-CSF through activating NF-kB, ERKs and Akt, but not JNKs, in a TLR2-dependent manner.

\section{Methods}

Mice

C57BL/6 J wild-type and TLR2 ${ }^{-/-}$(B6.129-Tlr2 $\left.{ }^{\text {tmlKir }} / J\right)$ mice were obtained from The Jackson Laboratory (Bar Harbor, ME, USA) and were maintained in the animal care and veterinary facility at the Western University or University of Montreal, respectively. Nod2 ${ }^{-/-}$mice obtained from Dr. Jean-Pierre Hugot [47] were maintained in the animal care and veterinary facility at the McGill University. Male and female mice, aged 4-10 weeks, were used in all experimental procedures. All experimental protocols were approved by the Western University Animal Use Subcommittee, which follows the regulations of the Animals for Research Act (Ontario) and the Canadian Council on Animal Care.

\section{Cell cultures, bacteria and reagents}

Bone marrow-derived immortalized macrophages from C57BL/6 J were generated as described previously [48] and cultured in RPMI 1640 medium (Sigma-Aldrich) supplemented with $10 \%$ heat-inactivated fetal bovine serum (Sigma-Aldrich), $1000 \mathrm{U}$ ml-1 penicillin, $10 \mathrm{mg} \mathrm{ml-1}$ streptomycin (Sigma-Aldrich), $5 \mathrm{mM}$ sodium pyruvate (Sigma-Aldrich), $5 \mathrm{mM}$ MEM nonessential amino acids (Sigma-Aldrich) (referred to as complete RPMI; c-RPMI). Cells were then maintained at $37{ }^{\circ} \mathrm{C}$ in a humidified atmosphere with $5 \% \mathrm{CO}_{2} . L$. rhamnosus GR-1, obtained from Dr. Gregor Reid (The Canadian Research and Development Centre for Probiotics, Lawson Health Research Institute, London, ON, Canada), was grown anaerobically in De Man, Rogosa and Sharpe (MRS) agar (Becton Dickinson) using anaerobic packs (Becton Dickinson) at $37^{\circ} \mathrm{C}$ for $48-72 \mathrm{~h}$. For cell culture challenge, L. rhamnosus GR-1 were grown from a single colony in MRS broth (Becton Dickinson) at $37^{\circ} \mathrm{C}$ for $24 \mathrm{~h}$. Uropathogenic E. coli GR-12, originally isolated from the urine of a patient with pyelonephritis [49], and Staphylococcus aureus strain Newman were grown aerobically overnight in Luria-Bertani medium (Becton Dickinson) and brain-heart infusion broth (Becton Dickinson), respectively, with agitation at $37{ }^{\circ} \mathrm{C}$. All bacteria were harvested by centrifugation at $6000 \mathrm{~g}$ for $10 \mathrm{~min}$, washed three times with phosphate-buffered saline (PBS) ( $\mathrm{pH} 7.4$ ), and diluted to obtain a final optical density of 1.0 at $600 \mathrm{~nm}$ (representing approximately $10^{9} \mathrm{CFU} / \mathrm{ml}$ ) in PBS. Lipopolysaccharide (LPS) from $E$. coli O111:B4 was from List Biological Laboratories 
(Campbell). PAM2 and PAM3 were purchased from Invivogen. LTA from S. aureus (indicated otherwise), lipase (from Candida rugosa), Cytochalasin D and RNase A were obtained from Sigma-Aldrich. DNase was purchased from Roche. LY294002, Akt inhibitor II, NF-kB activation inhibitor (CAS 545380-34-5), wortmannin, SB202190, U0126, and JNK inhibitor II were purchased from Calbiochem (EMD Biosciences). Antibodies for phospho-p38 (p-p38), p-ERKs, p-SAPK/JNKs, p-Akt, pinhibitor $\kappa B$ (IкB) and $\beta$-actin were purchased from Cell Signaling Technology (NEB Biosciences).

\section{Generation of primary bone marrow-derived macrophages (BMDMs)}

Bone marrow cells (BMCs) from wild-type, TLR2 ${ }^{-1-}$, $\mathrm{NOD}^{-1-}$, NOD2 ${ }^{-1-}$, and corresponding cross-matched wild-type mice for each knockout mouse were harvested from femurs and tibia of mice using a 25.5-gauge needle and PBS. Isolated cells were cultured in c-RPMI supplemented with murine recombinant macrophage (M)-CSF (20 ng/ml; eBioscience). Cells were then maintained at $37{ }^{\circ} \mathrm{C}$ in a humidified atmosphere with $5 \% \mathrm{CO}_{2}$ for 7 days. The culture media were replaced with fresh media every two days after culture initiation.

\section{Crude LTA purification}

Crude LTA was extracted from LGG and S. aureus using the butanol extraction method as previously described [50]. Briefly, bacterial cells were sonicated for $15 \mathrm{~min}$, re-suspended in $\mathrm{n}$-butanol/water (1:1, v/v) and stirred for $30 \mathrm{~min}$ at room temperature. The suspension was then centrifuged at $8000 \mathrm{~g}$ for $30 \mathrm{~min}$, resulting in a two-phase system. The aqueous phase was lyophilized to give crude LTA. Subsequently, the lyophilized sample was re-suspended in PBS and used for further experiments.

\section{Macrophage cell challenge and cytokine determination}

Macrophages were challenged in a 96-well plate format with 20 colony forming units (CFU/cell) of live bacteria, unless otherwise indicated, for $4 \mathrm{~h}$ in the presence of antibiotics-free media. Macrophages were then washed three times and further incubated with c-RPMI to prevent over-growth of bacteria and macrophage cell death. Macrophages were also treated with cell-free bacterial spent culture supernatant (SCS; 1/25 dilution), LTA $(10 \mu \mathrm{g} / \mathrm{ml})$ and LPS $(100 \mathrm{ng} / \mathrm{ml})$ in c-RPMI for the time indicated. Samples for TNF- $\alpha$ and G-CSF enzyme-linked immunosorbent assays (ELISA) were obtained from cell culture supernatant after 4 and 24 h challenges, respectively, unless otherwise indicated. Time points for TNF- $\alpha$ and G-CSF measurements were selected to maximize preferential production of G-CSF over TNF.

\section{ELISA}

To measure the TNF- $\alpha$ and G-CSF levels in cell culture supernatant, ELISA kits were purchased from eBioscience (San Diego, CA) and R\&D Systems (Minneapolis, MN), respectively. Standard curves were generated using recombinant proteins provided by the manufacturer.

\section{Western blot}

Total cell lysate extraction and Western blot analysis were performed as previously described [26]. Briefly, total cell lysates were extracted using ice-cold lysis buffer containing $20 \mathrm{mM}$ MOPS, $15 \mathrm{mM}$ EGTA, $2 \mathrm{mM}$ EDTA, $1 \mathrm{mM} \mathrm{Na}_{3} \mathrm{VO}_{4}, 1 \mathrm{mM}$ DTT, $75 \mathrm{mM} \beta$-glycerophosphate, $0.1 \mathrm{mM}$ PMSF, $1 \mu \mathrm{g} / \mathrm{mL}$ aprotinin, $10 \mu \mathrm{g} / \mathrm{mL}$ pepstatin A, $1 \mu \mathrm{g} / \mathrm{mL}$ leupeptin, and $1 \%$ Triton X-100. Following the incubation of cells with lysis buffer on ice for $5 \mathrm{~min}$, cell lysates were extracted by centrifuging the homogenate at $18000 \mathrm{~g}$ for $15 \mathrm{~min}$. Extracts were then mixed with SDSPAGE loading buffer, heated to $100{ }^{\circ} \mathrm{C}$ for $5 \mathrm{~min}$, resolved on $11 \%$ SDS-PAGE polyacrylamide gels (Bio-Rad), and transferred onto nitrocellulose membranes. Following that, membranes were blocked with $5 \%$ w/v skim milk for $30 \mathrm{~min}$, immunoblotted with antibodies, and visualized using an enhanced chemiluminescence detection system (ECL; Pierce Bioscience). Band intensity quantification was performed using ImageJ software (National Institutes of Health, Bethesda, MD).

\section{Cytokines and Chemokines PCR Array}

Total RNA was isolated using RNeasy Mini kit (QIAGEN Canada) according to the manufacture's recommendations. Reverse transcription was conducted using the $\mathrm{RT}^{2}$ First Strand Kit (QIAGEN) according to the manufacture's protocol. The Q-PCR was performed using the $\mathrm{RT}^{2}$ Profiler PCR Array System Kit for mouse cytokines and chemokines (QIAGEN) on an Applied Biosystems StepOnPlus instrument according to the manufacturer guidelines.

\section{Statistical analysis}

Pooled results of several independent experiments were used in all analyses. Results are reported as mean \pm SEM. Student's $t$-test or one-way analysis of variance (ANOVA) with Tukey's multiple comparison post hoc test were used to determine significance at $p<0.05$ among experimental groups using Prism 5.0c for Mac OS $\mathrm{X}$ (GraphPad Software, La Jolla, CA).

\section{Results}

Production of G-CSF is the most prominent among 84 cytokines and chemokines examined in GR-1-treated macrophages

We previously showed that GR-1 potently induces G-CSF but poorly induces TNF- $\alpha$ production in macrophages 
[28]. To further examine production of other cytokines induced by GR-1 and their levels in comparison to other stimuli, immortalized bone marrow-derived macrophages (BMDMs) were treated with live GR-1, LPS, $\mathrm{PAM}_{2} \mathrm{CSK}_{4}$ and $\mathrm{PAM}_{3} \mathrm{CSK}_{4}$ for $5 \mathrm{~h}$, and the expression of 84 cytokines and chemokines were examined using the $\mathrm{RT}^{2}$ Profiler PCR Array System Kit. As shown in Fig. 1 (upper left panel) and Additional file 1: Table S1, GR-1 potently induced expression of G-CSF mRNAs ( $>60$-fold of those induced in non-treated cells), whereas all others were induced less than 5-fold. LPS also induced G-CSF mRNA to $~ 80$-fold; however, it also potently induced other cytokines and chemokines, including CCL5, CCL12, CXCL1, CXCL3, CXCL9, CXCL10, CXCL11, IL-1 $\alpha / \beta$, IL-6, IL-12, TNF- $\alpha$ and TNF superfamily member 10 more than 50 fold. $\mathrm{PAM}_{2} \mathrm{CSK}_{4}$ and $\mathrm{PAM}_{3} \mathrm{CSK}_{4}$ also potently induced G-CSF more than 100-fold; however, they also induced IL- $1 \alpha / \beta$, IL-16 and TNF- $\alpha$ more than 50 -fold. These results demonstrate that GR-1 induced a cytokine/chemokine expression profile distinct from those of LPS, PAM2 and PAM3.

\section{Preferential G-CSF production by GR-1 is unique among} other tested bacteria in primary BMDM

We further examined whether preferential production of G-CSF was also observed in other bacteria and also in non-transformed macrophages. BMDMs derived from C57BL/6j mice were treated with live GR-1, E. coli GR-
12 , and S. aureus with 1-200 CFU/cell, and production of TNF- $\alpha$ (in $4 \mathrm{~h}$ ) and G-CSF (in $24 \mathrm{~h}$ ) were measured using ELISA. Both E. coli and S. aureus induced TNF- $\alpha$ as low as $1 \mathrm{CFU} /$ cell; whereas, GR-1 did not induce TNF- $\alpha$ even at 10 CFU/cell (Fig. 2a). GR-1 with higher than $20 \mathrm{CFU} / \mathrm{cell}$ induced TNF- $\alpha$, but the levels was less than one-half of those induced by $E$. coli and $S$. aureus. Unlike TNF- $\alpha$, G-CSF was significantly produced by all bacteria tested with similar maximal levels (Fig. 2b). GR1 induced G-CSF production as low as $10 \mathrm{CFU} /$ cell and maximally at $50 \mathrm{CFU} / \mathrm{cell}$. S. aureus also gradually induced G-CSF production starting at $1 \mathrm{CFU} /$ cell and maximally at $20 \mathrm{CFU} /$ cell. E. coli, however, maximally produced G-CSF even at $1 \mathrm{CFU} /$ cell. Collectively, these results suggest that $E$. coli and $S$. aureus induced both TNF- $\alpha$ and G-CSF in similar extents; whereas, GR-1 preferentially induced G-CSF over TNF- $\alpha$. Further examination on the kinetics of the production of these cytokines showed that GR-1 induced G-CSF $12 \mathrm{~h}$ after treatment at similar levels induced by LTA (Fig. 2c, right panel). Unlike G-CSF, production of TNF- $\alpha$ was induced as early as $4 \mathrm{~h}$ of LTA treatment. However, GR-1 did not induce TNF- $\alpha$ until $12 \mathrm{~h}$ post-treatment and the levels were significantly lower than those by LTA (Fig. 2c, left panel). Similar results were also obtained in immortalized BMDMs. These results suggest that live GR-1 preferentially produced G-CSF with similar kinetics as LTA without prominently inducing TNF- $\alpha$.

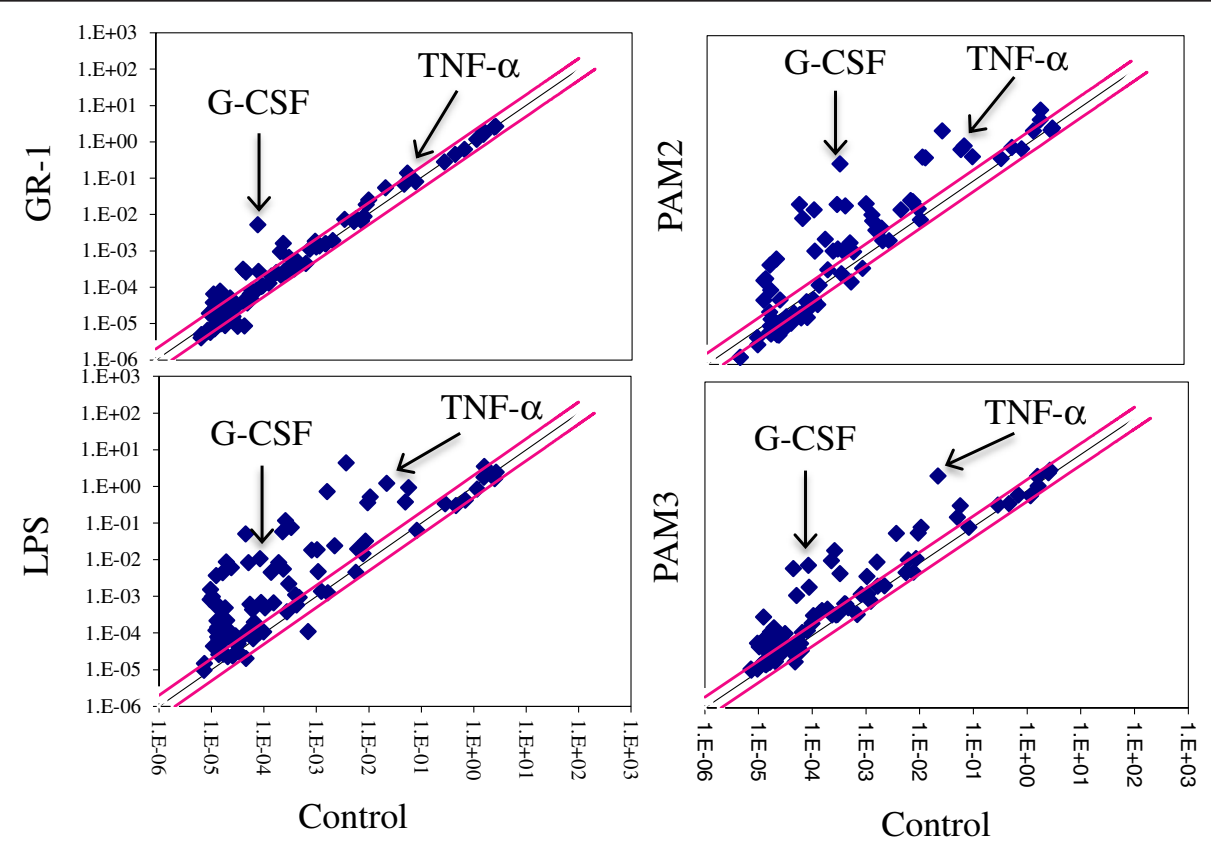

Fig. 1 Production of G-CSF is the most prominent among 84 cytokines and chemokines examined in GR-1-treated macrophages. Immortalized BMDMs were treated with GR-1 (20 CFU/cell), lipopolysaccharide (LPS; $100 \mathrm{ng} / \mathrm{ml})$, PAM $_{2} \mathrm{CSK}_{4}$ (PAM2; $\left.1 \mu \mathrm{g} / \mathrm{ml}\right)$ and PAM $\mathrm{CSK}_{4}$ (PAM3; $\left.1 \mu \mathrm{gg} / \mathrm{ml}^{2}\right)$ for 5 h. mRNA expression of various cytokines and chemokines were measured using the RT ${ }^{2}$ Profiler PCR Array System Kit for mouse cytokines and chemokines. Data represent average of two independent experiments 


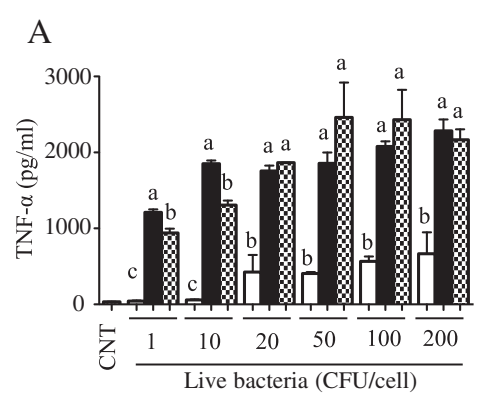

\section{B}
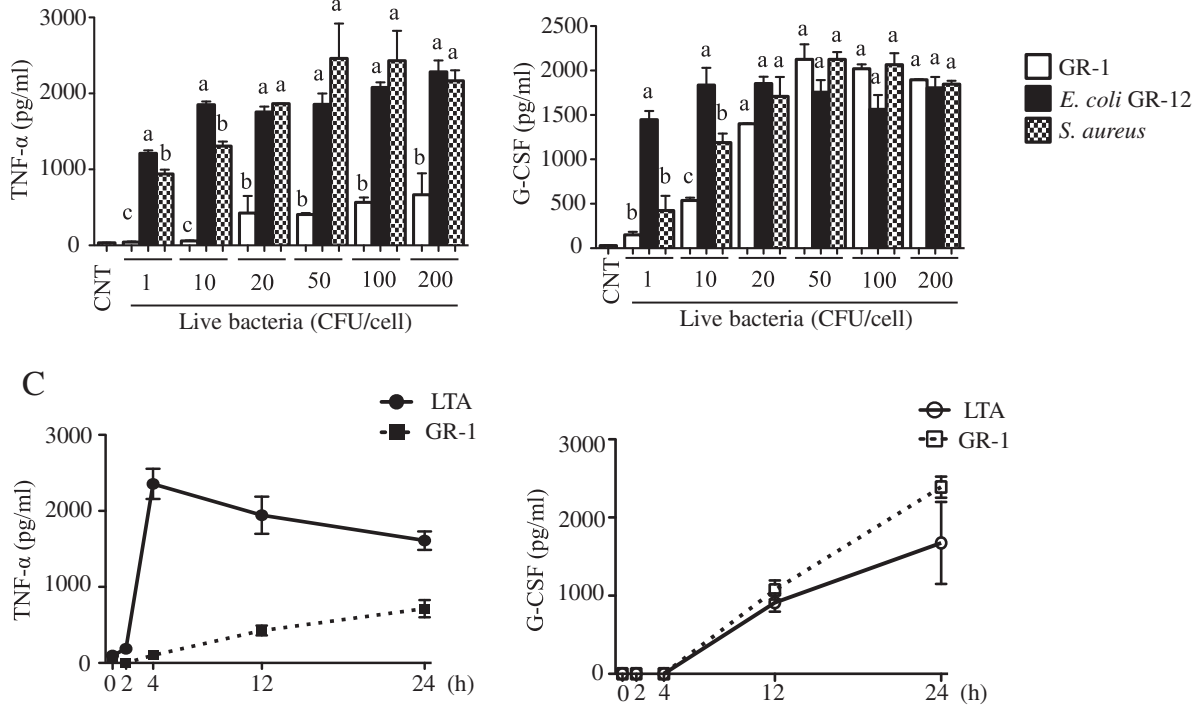

Fig. 2 Preferential G-CSF production by GR-1 is unique among other bacteria in primary BMDMs. a-b Primary BMDMs were treated with live $S$. aureus, live E. coli GR-12 or live GR-1 at indicated bacteria/macrophage ratios (CFU/cell). Production of TNF-a (a; in 4 h) and G-CSF (b; in 24 h) was measured from cell culture media using ELISA. [ $n \geq 3 ; p<0.05$ by one-way ANOVA with Tukey's multiple comparison post hoc test; columns accompanied by the same letter ( $\mathbf{a}, \mathbf{b}$ or $\mathbf{c}$ ) are not significantly different from each other]. $\mathbf{c}$ Primary BMDMs were treated with live GR-1 (20 CFU/cell) or lipoteichoic acid (LTA; $10 \mu \mathrm{g} / \mathrm{ml}$ ) for indicated time points. Production of TNF-a (in $4 \mathrm{~h}$ ) and G-CSF (in 24 h) was measured from cell culture media using ELISA. Data shown as mean \pm SEM $[n \geq 3]$

Activation of ERKs, NF-KB and Akt but not JNKs by GR-1 plays a key role in the preferential production of G-CSF over TNF-a

To examine signaling pathways activated by GR-1, immortalized BMDMs were treated with GR-1 at $20 \mathrm{CFU} /$ cell for different time points and Western blots against phosphorylated $\mathrm{I} k \mathrm{~B}$, Akt, and mitogen-activated protein kinases (MAPKs; ERKs, p38 and JNKs) were performed. Consistent with previous studies [51, 52], LTA activated all MAPKs, Akt and NF- $\mathrm{kB}$ signaling cascades after 15-30 min of treatment (Fig. 3a). GR-1 also potently activated ERKs, but weakly p38, Akt and NF-kB. However, no activation of JNKs by GR-1 was detected. To further examine which of these signaling cascades were involved in G-CSF and TNF- $\alpha$ production, these cells were pretreated with various inhibitors, and then treated with GR-1 or LTA. As shown in Fig. 3b, production of G-CSF by GR-1 and LTA was inhibited by the NF- $\mathrm{B}$ inhibitor $(\mathrm{NF}-\mathrm{kBi})$, ERKs inhibitor (U0126), phosphatidylinositol 3-kinase (PI3K) inhibitor (wortmanin or LY94002) and Akt inhibitor (Akt inhibitor II), but not by the p38 inhibitor (SB203580) and JNKs inhibitor (JNK inhibitor II). Unlike G-CSF, the production of TNF- $\alpha$ by LTA was inhibited by all the MAPK inhibitors (U0126, SB203580 \& JNK inhibitor II), but not by the PI3K and Akt inhibitors (wortmanin, LY94002 and Akt inhibitor II). These results suggest that activations of ERKs, NF- $\mathrm{B}$ and Akt without activation of
JNKs lead the preferential production of G-CSF over TNF- $\alpha$ in response to GR-1.

\section{TLR2 plays a key role in inducing G-CSF in GR-1-treated primary BMDM}

GR-1, as a Gram-positive bacterium, harbors several MAMPs, including lipoproteins/LTA and peptidoglycan, which activate TLR2 and NOD1/2, respectively. Also macrophages are professional phagocytes, and activation of these receptors and subsequent signaling events are coordinated by phagocytosis [53-55]. Thus, we examined if phagocytosis was involved in the preferential production of G-CSF, using the actin polymerization inhibitor cytochalasin D (CytD; $5 \mu \mathrm{g} / \mathrm{ml})$. As shown in Fig. 4a, CytD pre-treatment inhibited G-CSF production induced by live GR-1 but not LTA, suggesting that phagocytosis of GR-1 was necessary for the production of G-CSF in macrophages. Since TLR2 and NOD1/2 are main receptors activated by Gram-positive bacteria, we then examined if these receptors are involved in GR-1induced G-CSF production, using BMDM derived from TLR2-, NOD1- and NOD2-deficinent mice exposed to GR-1, $\mathrm{PAM}_{3} \mathrm{CSK}_{4}$ or LTA. G-CSF production was normal in NOD1 - and NOD2-deficient, but undetectable in TLR2-deficient BMDMs in response to either GR-1 or $\mathrm{PAM}_{3} \mathrm{CSK}_{4}$ (Fig. 4b). NOD1- and NOD2-deficient BMDMs also produced similar levels of TNF- $\alpha$ as wildtype BMDMs by GR-1 and LTA, whereas TLR2-deficient 


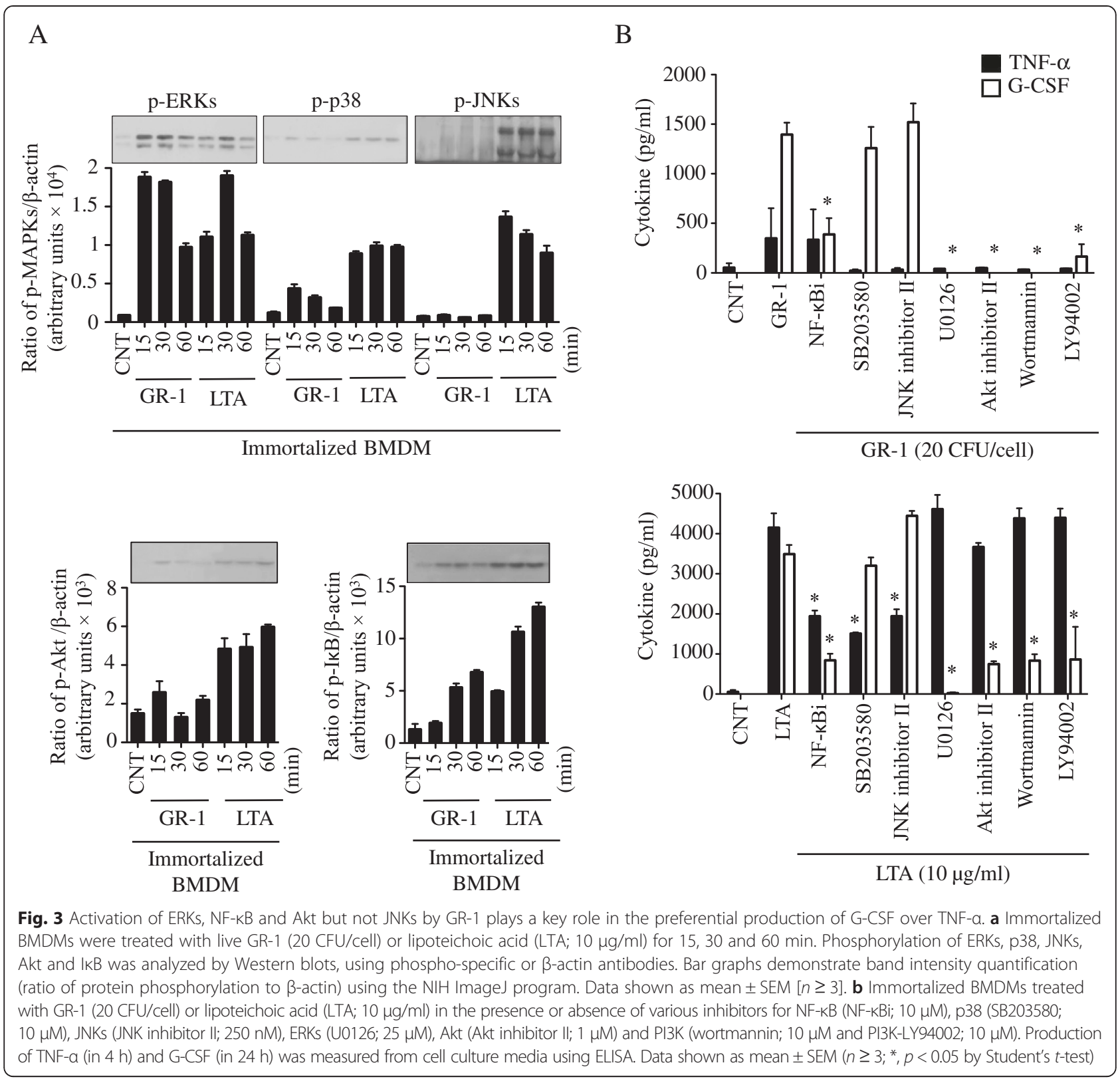

BMDMs failed to produce TNF- $\alpha$ by either GR-1 or $\mathrm{PAM}_{3} \mathrm{CSK}_{4}$. Consistent with these results, TLR2deficient primary BMDMs did not activate ERKs, p38, Akt and NF-kB in response to GR-1 (Fig. 4d). GR-1 activated JNKs in neither wild-type nor TLR2-deficient BMDMs (data not shown), as in immortalized BMDMs (Fig. 3a). These data suggest that production of G-CSF and activation of ERKS, p38, Akt and NF- $\mathrm{kB}$ by GR-1 was mediated through TLR2.

\section{A heat-labile protein-like molecule(s) secreted by GR-1 preferentially induces G-CSF production}

Since TLR2 activation was required for G-CSF production by GR-1, we further examined whether crude LTA prepared from GR-1 induced a similar G-CSF preferential production effect in immortalized BMDMs. LTA from GR-1 was 10-fold less effective in inducing both G-CSF and TNF- $\alpha$ than LTA prepared from S. aureus (Fig. 5a). However, unlike live GR-1, LTA from GR-1 induced both TNF- $\alpha$ and G-CSF at similar levels, suggesting that LTA was not the factor responsible for the preferential production of G-CSF. We then examined whether a factor(s) released from GR-1 had a similar effect on G-CSF production as in live GR-1. As shown in Fig. 5b, GR-1 cell free spent culture supernatant (SCS), but not the media (MRS), preferentially produced G-CSF over TNF- $\alpha$, and the production of G-CSF was abolished in SCS treated with heat $\left(95^{\circ} \mathrm{C}\right.$ for $\left.3 \mathrm{~h}\right)$, trypsin and proteinase $\mathrm{K}$, but 


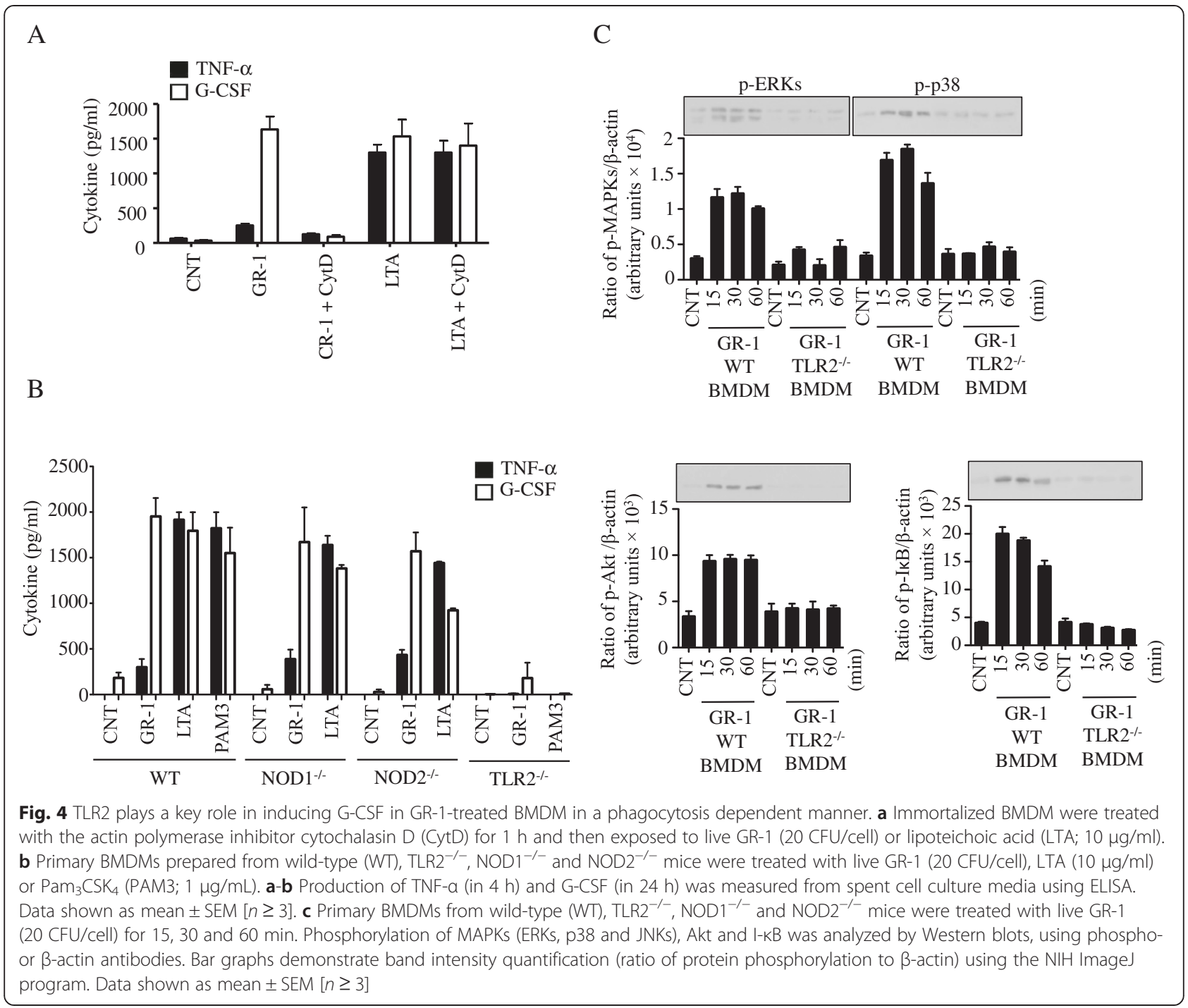

not with lipase, DNase and RNase (Fig. 5b). Treatments of trypsin or proteinase $\mathrm{K}$ had no effects on LPS-induced TNF- $\alpha$ and G-CSF production, indicating that inhibition of G-CSF production in GR-1 SCS was not due to residual effects of these proteases on macrophages. To estimate the native molecular size(s) of the GR-1 molecule(s), GR1-SCS was filtered through different membrane sizes. As shown in Fig. 5c, the molecule(s) passed through $100 \mathrm{kDa}$ membranes but not $30 \mathrm{kDa}$ membranes, suggesting that the GR-1 molecule(s) was between 100 and $30 \mathrm{kDa}$ in native size. Collectively, these results indicate that the GR-1 factor(s) responsible for preferential G-CSF production in macrophages is a heat-labile protein-like molecule(s) of $30-100 \mathrm{kDa}$ in native size.

\section{Discussion}

Here, we showed that among 84 cytokines/chemokines examined, GR-1 uniquely and potently induced G-CSF
(Fig. 1 and Additional file 1: Table S1), and the production of G-CSF by GR-1 was as efficient as other known pro-inflammatory stimuli in both kinetics and amounts (Fig. 2). This observation is consistent with our previous studies in macrophages [26, 28] and placental trophoblast cells that showed high levels of G-CSF production by GR-1 [22, 23]. GR-1 at higher than $20 \mathrm{CFU} /$ cell or after $12 \mathrm{~h}$ post-exposure was able to induce TNF- $\alpha$, albeit at significantly lower levels than those induced by E. coli GR-12 or S. aureus (Fig. 2). Since over-growth of GR-1 even after thorough wash and incubation with antibiotics containing cell culture media was detected, it is possible that the production of TNF- $\alpha$ in macrophages treated with GR-1 for 12$24 \mathrm{~h}$ could be due to high numbers of GR-1 (Fig. 2a and c). Nonetheless, GR-1 induced TNF- $\alpha$ much less efficiently when compared to other bacteria or LTA, which is consistent with previous studies shown in 


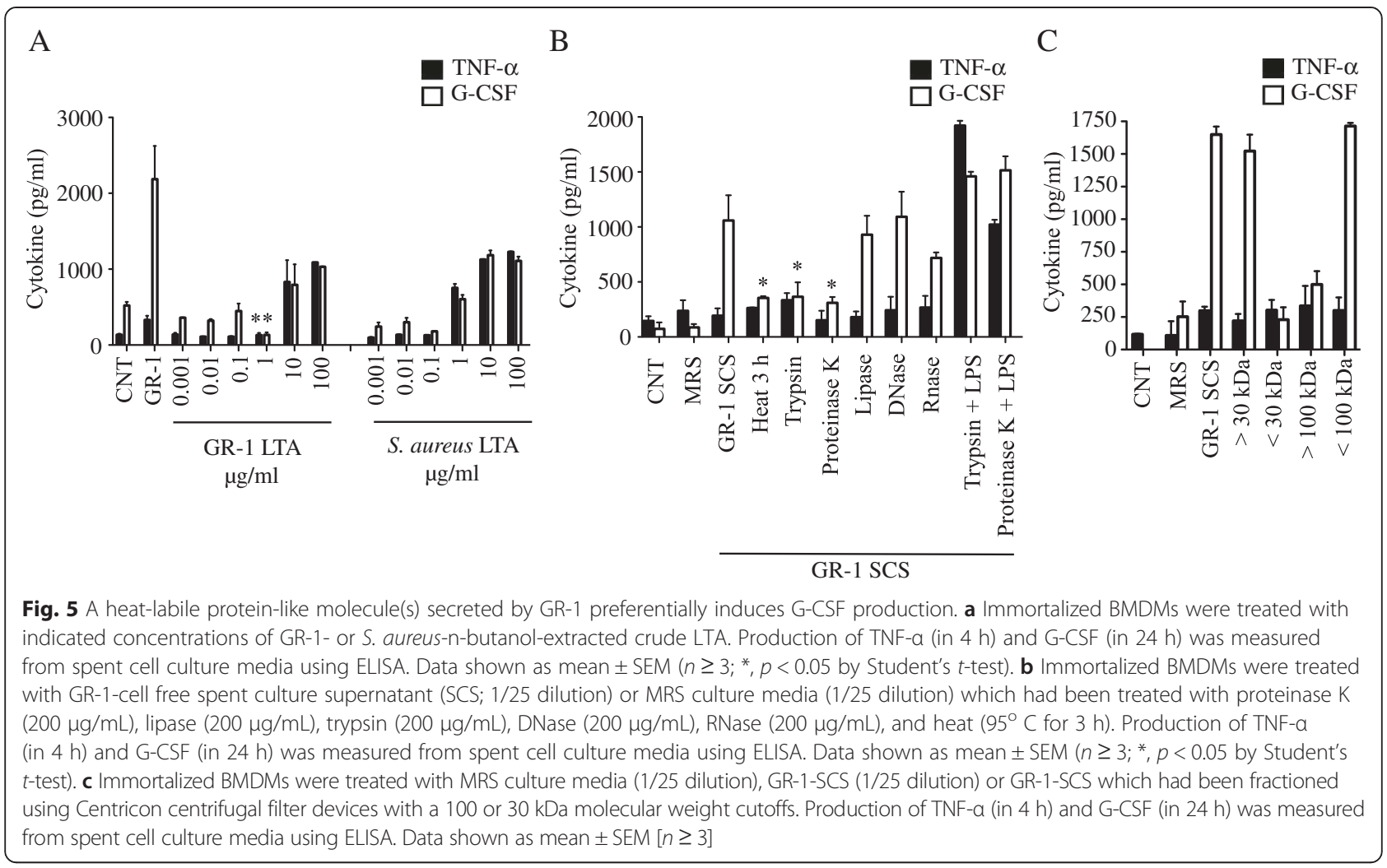

human bladder cells exposed to live GR-1 or GR-1 SCS $[24,25]$.

Inefficient production of TNF- $\alpha$ by GR-1 was in part due to poor stimulatory effects of GR-1 cell wall components. LTA prepared from GR-1 was 10-fold less efficient in inducing TNF- $\alpha$ when compared to LTA similarly prepared from $S$. aureus (Fig. 5a). Previous studies have also shown that LTA purified from several strains of Lactobacillus, including L. plantarum str. WCFS1 [34], L. casei str. YIT9029 [35], L. fermentum YIT0159 [35] and LGG [56] are inefficient in producing pro-inflammatory cytokines such as TNF- $\alpha$, IL- $1 \beta$ and IL-6. It is still unknown why LTAs from several strains of Lactobacillus are inefficient in inducing proinflammatory cytokines. Interestingly, mutant $L$. plantarum WCFS1 and LGG that lacks D-alanylated LTA induces more anti-inflammatory but less pro-inflammatory cytokines in monocytes than wild-type LTA [34], and rendered protective effects on colitis [12, 34]. However, in another study, alanylation of LTA had no role in the production of pro-inflammatory cytokines in LGGtreated macrophages and peripheral mononuclear cells [56]. Regardless the levels of alanylation, GR-1 LTA is not likely involved in the G-CSF preferential effect of GR-1, as GR-1 LTA at high doses induced both TNF- $\alpha$ and G-CSF at similar extents (Fig. 5a). Another cell wall component shown to be involved in immunomodulation by Lactobacillus is peptidoglycan [33, 57]. NOD1 and 2 are PRRs that recognize the peptidoglycan fragments $\gamma$ D-glutamyl-mesodiaminopimelic acid and muramyl dipeptides, respectively [58, 59]. However, GR-1 potently and preferentially induced G-CSF in macrophages deficient in either NOD1 or NOD2 (Fig. 4b), suggesting that GR-1 peptidoglycan is not involved in G-CSF preferential production by GR-1.

At this moment, the identity of GR-1 factor(s) responsible for the preferential production of G-CSF is elusive. This study suggested that a protein-like factor, which is sensitive to heat and proteases, such as trypsin and proteinase $\mathrm{K}$, with a native molecular weight between 30 and $100 \mathrm{kDa}$, is responsible for G-CSF preferential production by GR-1 (Fig. 5b-c). To date, probiotic proteins known to preferentially induce anti-inflammatory cytokines include surface layer proteins from $L$. reuteri, $L$. casei, [60] and L. acidophilus NCFM [38], and bacteriocins released from L. plantarum strains [40, 61]. Immunomodulation elicited by surface layer proteins likely acts through DC-SIGN (DC-specific ICAM3-grabbing nonintegrin) [60, 62], which is distinct from the GR-1 factor(s) that required TLR2 (Fig. 4a). Secreted factors of L. rhamnosus CNCM I-4036 and Bifidobacterium breve CNCM I4035 were shown to be more potent than live bacteria counterpart in suppressing production of pro-inflammatory cytokines induced by E. coli or Salmonella typhi, respectively, in DCs [63, 64]. However, the identities of these factors are still unknown. Various Lactobacillus species, 
including L. rhamnosus, release bacteriocins which can directly modulate immune responses $[61,65,66]$. Therefore, bacteriocin-related proteins released by GR-1 may have been involved in the G-CSF production. Further studies on the possible involvement of bacteriocin-related proteins in G-CSF production are warranted.

GR-1 was shown to release factors that have immunomodulatory effects on non-immune cells. GR-1 SCS significantly induced G-CSF and macrophage inflammatory protein $1 \alpha / \beta$, but suppressed various LPS-induced proinflammatory cytokines including TNF- $\alpha$ in human decidual cells [67] and in CD-1 pregnant mice [68]. However, in urinary bladder cells, GR-1 SCS enhanced activation of NF- $\mathrm{BB}$ [24] and production of TNF- $\alpha$, but not IL-6 and IL-8, induced by E. coli [25]. In these studies, GR-1 or GR-1 SCS alone induced NF- $\mathrm{kB}$ but little TNF- $\alpha$ production, which is consistent with our results (Fig. $3 \mathrm{a}$ and $4 \mathrm{~b}$ ). Although it is unknown whether these responses are mediated by the same factor, molecular characteristics in a protein-like entity with native molecular size above $30 \mathrm{kDa}$ appear to be common in both studies (Fig. 5) [24].

We further examined the signaling pathways required for G-CSF preferential production in GR-1-treated macrophages. GR-1 activated ERKs, p38, Akt and NF-kB, but not JNKs, in immortalized and primary BMDM in a TLR2-dependent manner (Fig. 3a and 4). Based on experiments using specific inhibitors, activation of ERKs, Akt and NF- $\mathrm{KB}$ was involved in G-CSF production, whereas activation of ERKs, p38, JNKs and NF- $\mathrm{kB}$ pathways was required for TNF- $\alpha$ production (Fig. 3b). These results are consistent with previous reports showing that p38 and JNKs are required for production of pro-inflammatory cytokines, such as TNF- $\alpha$, IL-1 $\beta$, IL-6 and IL-8 $[69,70]$. Also, p38 and JNKs, but not ERKs, are involved in the signal transduction of LPS-induced TNF- $\alpha$ and IL-1 $\beta$ production by Kupffer cells [71] and RAW 264.7 macrophages [72]. Therefore, lack of JNKs activation in GR-1-treated macrophages likely contributed to the inefficient production of pro-inflammatory cytokines. The PI3K/Akt signaling axis can suppress TNF- $\alpha$ production through multiple pathways [73], particularly through inactivating NF-kB but activating CAMP response-binding protein (CREB), resulting in suppression of IL-12 and induction of IL-10 production [74]. We showed that the inhibitors specific for Akt or PI3K inhibited TNF- $\alpha$, but not G-CSF, production (Fig. 3b). These results are consistent with previous studies showing that activation of ERKs, NF- $\mathrm{kB}$ and PI3K/Akt pathways are crucial for G-CSF expression [75, 76]. Recent studies also showed that activation of PI3K/Akt is required for TLR-mediated G-CSF production, through inducing expression of the transcription factor octamer-binding factor-2 (Oct-2) [77, 78]. Therefore, activation of PI3K/
Akt and ERKs pathways by GR-1 is likely involved in the preferential production of G-CSF in GR-1-treated macrophages.

An intriguing fact is that G-CSF production by GR-1 required phagocytosis and TLR2 (Fig. 4a-b). We found that phagocytosis of GR-1 was required for efficient production of G-CSF (Fig. 4a). Recent studies have shown that TLR2 mediates signaling from endosomal vesicles, in addition to the plasma membrane, particularly during Borrelia burgdorferi infection $[79,80]$. Therefore, it is possible that phagocytosis is required for the activation of endosomal TLR2 by a ligand(s) released or secreted from GR-1. Further studies are required to unravel whether GR-1 mainly activates endo/phagosomal TLR2. At this moment, it is also unknown how activation of TLR2 by GR-1 led to ERKs and p38 activation without JNKs activation, resulting in G-CSF production without inducing pro-inflammatory cytokines. However, the anti-inflammatory responses by activating TLR2 are not restricted in GR-1. Bifidobacterium pseudocatenulatum CECT7765 was recently shown to produce anti-inflammatory cytokines such as IL-10 and suppress TNF- $\alpha$ production through TLR2 [81]. Even purified LTA or whole cells from lactobacilli were previously shown to modulate TNF- $\alpha$ expression through a TLR2dependent mechanism [34, 35, 82, 83]. Further experiments delineating mechanisms of TLR2 in activating immunomodulatory responses is of great interest.

The primary function of G-CSF in the generation and mobilization of neutrophils, G-CSF enhances antimicrobial function of mature neutrophils [84-86], and regulates immune responses through suppressing production of various pro-inflammatory cytokines in myeloid cells [26, 27], generating regulatory gut-homing macrophages [87], promoting maturation of tolerogenic DCs $[28,88,89]$ and generation of IL-10-secreting $\mathrm{CD}^{+}$type $1 \mathrm{~T}$ regulatory cells [90]. Therefore, G-CSF production by GR-1 may play an important role in enhancing antibacterial activities of neutrophils and preventing cell death of intestinal/urogenital epithelial cells induced by various stresses, without inducing inflammatory responses. Beneficial effects of probiotics are not limited in the intestine. Interestingly, a recent study showed that administration of L. plantarum 299v or GR-1 protected cardiac failure and hypertrophy in the rat heart $[91,92]$. Since G-CSF also renders cytoprotective effects against various stresses in neuronal and cardiac cells [93-95], we are tempted to speculate that G-CSF may also contribute to the cardioprotective effects of L. plantarum 299v or GR-1.

\section{Conclusion}

In summary, this study demonstrated that a protein-like factor(s) from GR-1 preferentially and potently produced G-CSF in macrophages through selectively activating ERKs, NF-kB and Akt in a TLR2-dependent manner. 


\section{Additional file}

Additional file 1: Table S1. Expression of cytokines and chemokines in immortalized BMDMs treated with GR-1 and TLR ligands. (DOC 105 kb)

\section{Abbreviations}

BMCs: Bone marrow cells; BMDM: Bone marrow-derived macrophages; CFU: Colony forming units; CytD: Cytochalasin D; DC: Dendritic cell; ECL: Enhanced chemiluminescence detection system; ELISA: Enzyme-linked immunosorbent assays; ERKs: Extracellular regulated protein kinases; G-CSF: Granulocyte colony-stimulating factor; GR-1: Lactobacillus rhamnosus GR-1; IL: Interleukin; IKB: inhibitory KB; JNKs: c-Jun N-terminal kinases; LGG: Lactobacillus rhamnosus GG; LPS: Lipopolysaccharide; LTA: Lipoteichoic acid; MAMP: Microbe-associated molecular pattern; MAPKs: Mitogen-activated protein kinases; NF-kB: Nuclear factor kappa-light-chain-enhancer of activated B cells; NOD: Nucleotide-binding oligomerization domain; PBS: Phosphate buffered saline; PI3K: Phosphatidylinositol 3-kinase; PRRs: Pattern recognition receptors; SCS: Spent culture supernatant; SDS-PAGE: Sodium dodecyl sulfate polyacrylamide gel electrophoresis; TLR: toll-like receptor; TNF-a: tumor necrosis factor-a.

\section{Competing interests}

The authors declare that they have no competing interests.

\section{Authors' contributions}

SM carried out all experiments, involved in the design of the experiments, analyzed data, drafted the manuscript. JF provided key reagents (NOD 1- and 2-deficient mice), involved in the design of the experiments and helped to draft the manuscript. MG provided key reagents (TLR2-deficient mice), involved in the design of the experiments and helped to draft the manuscript. SOK conceived of the study, involved in the design, analysis, coordination of the experiments, and drafted the manuscript. All authors read and approved the final manuscript.

\section{Acknowledgement}

We thank Dr. Reid for providing L. rhamnosus GR-1 and Ms. Chantelle Reid for editing the manuscript. The study was supported by the Natural Sciences \& Engineering Research of Canada (No. RGPIN 312482-2013) to SOK.

\section{Author details}

1 Department of Microbiology and Immunology and Infectious Diseases Research Group, Siebens-Drake Research Institute, Western University, London, ON N6G 2 V4, Canada. ${ }^{2}$ Center for Human Immunology, Western University, London, ON N6G 2 V4, Canada. ${ }^{3}$ Department of Microbiology, McGill University, Montreal, QC H3G OB1, Canada. ${ }^{4}$ Faculty of Veterinary Medicine, University of Montreal, St-Hyacinthe, QC J2S 2 M2, Canada.

Received: 11 May 2015 Accepted: 19 October 2015

Published online: 26 October 2015

\section{References}

1. Klein M, Sanders ME, Duong T, Young HA. Probiotics: from bench to market. Ann N Y Acad Sci. 2010;1212 Suppl 1:E1-14.

2. Reid G, Younes JA, Van der Mei HC, Gloor GB, Knight R, Busscher HJ. Microbiota restoration: natural and supplemented recovery of human microbial communities. Nat Rev Microbiol. 2010;9(1):27-38.

3. Holzapfel WH, Haberer $P$, Snel J, Schillinger U, Huis in't Veld JH. Overview of gut flora and probiotics. Int J Food Microbiol. 1998;41(2):85-101.

4. Ravel J, Gajer P, Abdo Z, Schneider GM, Koenig SS, McCulle SL, et al. Vaginal microbiome of reproductive-age women. Proc Natl Acad Sci U S A. 2011;108 Suppl 1:4680-7.

5. Ashraf R, Shah NP. Immune system stimulation by probiotic microorganisms. Crit Rev Food Sci Nutr. 2014;54(7):938-56.

6. Lievin-Le Moal V, Servin AL. Anti-infective activities of lactobacillus strains in the human intestinal microbiota: from probiotics to gastrointestinal anti-infectious biotherapeutic agents. Clin Microbiol Rev. 2014;27(2):167-99.

7. Jensen H, Dromtorp SM, Axelsson L, Grimmer S. Immunomodulation of monocytes by probiotic and selected lactic Acid bacteria. Probiotics Antimicrob Proteins. 2015;7(1):14-23.
8. Vargas Garcia CE, Petrova M, Claes IJ, De Boeck I, Verhoeven TL, Dilissen E, et al. Piliation of Lactobacillus rhamnosus GG promotes adhesion, phagocytosis, and cytokine modulation in macrophages. Appl Environ Microbiol. 2015;81(6):2050-62.

9. Wu CT, Chen PJ, Lee YT, Ko JL, Lue KH. Effects of immunomodulatory supplementation with Lactobacillus rhamnosus on airway inflammation in a mouse asthma model. J Microbiol Immunol Infect. 2014.

10. Foster LM, Tompkins TA, Dahl WJ. A comprehensive post-market review of studies on a probiotic product containing Lactobacillus helveticus R0052 and Lactobacillus rhamnosus R0011. Benef Microbes. 2011;2(4):319-34.

11. Mileti $E$, Matteoli G, Iliev ID, Rescigno M. Comparison of the immunomodulatory properties of three probiotic strains of Lactobacilli using complex culture systems: prediction for in vivo efficacy. PLoS One. 2009:4(9), e7056.

12. Claes IJ, Lebeer S, Shen C, Verhoeven TL, Dilissen E, De Hertogh G, et al. Impact of lipoteichoic acid modification on the performance of the probiotic Lactobacillus rhamnosus GG in experimental colitis. Clin Exp Immunol. 2010;162(2):306-14

13. Pena JA, Versalovic J. Lactobacillus rhamnosus GG decreases TNF-alpha production in lipopolysaccharide-activated murine macrophages by a contact-independent mechanism. Cell Microbiol. 2003;5(4):277-85.

14. Gosselink MP, Schouten WR, van Lieshout LM, Hop WC, Laman JD, Ruseler-van Embden JG. Delay of the first onset of pouchitis by oral intake of the probiotic strain Lactobacillus rhamnosus GG. Dis Colon Rectum. 2004;47(6):876-84.

15. Moon G, Myung SJ, Jeong JY, Yang SK, Cho YK, Lee SM, et al. Prophylactic effect of Lactobacillus GG in animal colitis and its effect on cytokine secretion and mucin gene expressions. Korean J Gastroenterol. 2004:43(4):234-45

16. Yan F, Cao H, Cover TL, Whitehead R, Washington MK, Polk DB. Soluble proteins produced by probiotic bacteria regulate intestinal epithelial cell survival and growth. Gastroenterology. 2007;132(2):562-75.

17. Yan F, Polk DB. Probiotic bacterium prevents cytokine-induced apoptosis in intestinal epithelial cells. J Biol Chem. 2002;277(52):50959-65.

18. Yan F, Cao H, Cover TL, Washington MK, Shi Y, Liu L, et al. Colon-specific delivery of a probiotic-derived soluble protein ameliorates intestinal inflammation in mice through an EGFR-dependent mechanism. J Clin Invest. 2011;121(6):2242-53.

19. Reid G, Charbonneau D, Erb J, Kochanowski B, Beuerman D, Poehner R, et al. Oral use of Lactobacillus rhamnosus GR-1 and L. fermentum RC-14 significantly alters vaginal flora: randomized, placebo-controlled trial in 64 healthy women. FEMS Immunol Med Microbiol. 2003;35(2):131-4.

20. Gardiner GE, Heinemann C, Bruce AW, Beuerman D, Reid G. Persistence of Lactobacillus fermentum RC-14 and Lactobacillus rhamnosus GR-1 but not L. rhamnosus GG in the human vagina as demonstrated by randomly amplified polymorphic DNA. Clin Diagn Lab Immunol. 2002;9(1):92-6.

21. Marelli G, Papaleo E, Ferrari A. Lactobacilli for prevention of urogenital infections: a review. Eur Rev Med Pharmacol Sci. 2004;8(2):87-95.

22. Yeganegi M, Leung CG, Martins A, Kim SO, Reid G, Challis JR, et al. Lactobacillus rhamnosus GR-1-induced IL-10 production in human placental trophoblast cells involves activation of JAK/STAT and MAPK pathways. Reprod Sci. 2010;17(11):1043-51.

23. Yeganegi M, Leung CG, Martins A, Kim SO, Reid G, Challis JR, et al. Lactobacillus rhamnosus GR-1 stimulates colony-stimulating factor 3 (granulocyte) (CSF3) output in placental trophoblast cells in a fetal sex-dependent manner. Biol Reprod. 2011;84(1):18-25.

24. Karlsson M, Scherbak N, Khalaf H, Olsson PE, Jass J. Substances released from probiotic Lactobacillus rhamnosus GR-1 potentiate NF-kappaB activity in Escherichia coli-stimulated urinary bladder cells. FEMS Immunol Med Microbiol. 2012;66(2):147-56.

25. Karlsson M, Scherbak N, Reid G, Jass J. Lactobacillus rhamnosus GR-1 enhances NF-kappaB activation in Escherichia coli-stimulated urinary bladder cells through TLR4. BMC Microbiol. 2012;12:15.

26. Kim SO, Sheikh HI, Ha SD, Martins A, Reid G. G-CSF-mediated inhibition of JNK is a key mechanism for Lactobacillus rhamnosus-induced suppression of TNF production in macrophages. Cell Microbiol. 2006:8(12):1958-71.

27. Martins AJ, Colquhoun P, Reid G, Kim SO. Reduced expression of basal and probiotic-inducible G-CSF in intestinal mononuclear cells is associated with inflammatory bowel disease. Inflamm Bowel Dis. 2009;15(4):515-25.

28. Martins AJ, Spanton S, Sheikh HI, Kim SO. The anti-inflammatory role of granulocyte colony-stimulating factor in macrophage-dendritic cell crosstalk after Lactobacillus rhamnosus GR-1 exposure. J Leukoc Biol. 2011. 
29. Lorea Baroja M, Kirjavainen PV, Hekmat S, Reid G. Anti-inflammatory effects of probiotic yogurt in inflammatory bowel disease patients. Clin Exp Immunol. 2007;149(3):470-9.

30. Sansonetti PJ. War and peace at mucosal surfaces. Nat Rev Immunol. 2004;4(12):953-64.

31. lijima N, Thompson JM, Iwasaki A. Dendritic cells and macrophages in the genitourinary tract. Mucosal Immunol. 2008;1(6):451-9.

32. Plaza-Diaz J, Gomez-Llorente C, Fontana L, Gil A. Modulation of immunity and inflammatory gene expression in the gut, in inflammatory diseases of the gut and in the liver by probiotics. World J Gastroenterol. 2014;20(42):15632-49.

33. Macho Fernandez E, Valenti V, Rockel C, Hermann C, Pot B, Boneca IG, et a Anti-inflammatory capacity of selected lactobacilli in experimental colitis is driven by NOD2-mediated recognition of a specific peptidoglycan-derived muropeptide. Gut. 2011;60(8):1050-9.

34. Grangette C, Nutten S, Palumbo E, Morath S, Hermann C, Dewulf J, et al. Enhanced antiinflammatory capacity of a Lactobacillus plantarum mutant synthesizing modified teichoic acids. Proc Natl Acad Sci U S A. 2005;102(29):10321-6.

35. Kim HG, Lee SY, Kim NR, Ko MY, Lee JM, Yi TH, et al. Inhibitory effects of Lactobacillus plantarum lipoteichoic acid (LTA) on Staphylococcus aureus LTA-induced tumor necrosis factor-alpha production. J Microbiol Biotechnol. 2008;18(6):1191-6.

36. Kaji R, Kiyoshima-Shibata J, Nagaoka M, Nanno M, Shida K. Bacterial teichoic acids reverse predominant IL-12 production induced by certain lactobacillus strains into predominant IL-10 production via TLR2-dependent ERK activation in macrophages. J Immunol. 2010;184(7):3505-13.

37. Yasuda E, Serata M, Sako T. Suppressive effect on activation of macrophages by Lactobacillus casei strain Shirota genes determining the synthesis of cell wall-associated polysaccharides. Appl Environ Microbiol. 2008;74(15):4746-55.

38. Konstantinov SR, Smidt H, de Vos WM, Bruijns SC, Singh SK, Valence F, et al. $\mathrm{S}$ layer protein A of Lactobacillus acidophilus NCFM regulates immature dendritic cell and T cell functions. Proc Natl Acad Sci U S A. 2008;105(49):19474-9.

39. Azcarate-Peril MA, Altermann E, Hoover-Fitzula RL, Cano RJ, Klaenhammer TR. Identification and inactivation of genetic loci involved with Lactobacillus acidophilus acid tolerance. Appl Environ Microbiol. 2004;70(9):5315-22.

40. Meijerink M, van Hemert S, Taverne N, Wels M, de Vos P, Bron PA, et al. Identification of genetic loci in Lactobacillus plantarum that modulate the immune response of dendritic cells using comparative genome hybridization. PLoS One. 2010;5(5), e10632.

41. Ganguli K, Collado MC, Rautava J, Lu L, Satokari R, von Ossowski I, et al. Lactobacillus rhamnosus GG and its SpaC pilus adhesin modulate inflammatory responsiveness and TLR-related gene expression in the fetal human gut. Pediatr Res. 2015;77(4):528-35.

42. Thomas CM, Hong T, van Pijkeren JP, Hemarajata P, Trinh DV, Hu W, et al. Histamine derived from probiotic Lactobacillus reuteri suppresses TNF via modulation of PKA and ERK signaling. PLoS One. 2012;7(2), e31951.

43. Hemarajata P, Gao C, Pflughoeft KJ, Thomas CM, Saulnier DM, Spinler JK, et al. Lactobacillus reuteri-specific immunoregulatory gene rsiR modulates histamine production and immunomodulation by Lactobacillus reuteri. J Bacteriol. 2013;195(24):5567-76.

44. Fitzpatrick LR, Small J, Hoerr RA, Bostwick EF, Maines L, Koltun WA. In vitro and in vivo effects of the probiotic Escherichia coli strain M-17: immunomodulation and attenuation of murine colitis. Br J Nutr. 2008;100(3):530-41

45. Watanabe T, Nishio H, Tanigawa T, Yamagami H, Okazaki H, Watanabe K, et al. Probiotic Lactobacillus casei strain Shirota prevents indomethacin-induced small intestinal injury: involvement of lactic acid. Am J Physiol Gastrointest Liver Physiol. 2009;297(3):G506-13.

46. Hosoya T, Sakai F, Yamashita M, Shiozaki T, Endo T, Ukibe K, et al. Lactobacillus helveticus SBT2171 inhibits lymphocyte proliferation by regulation of the JNK signaling pathway. PLoS One. 2014;9(9), e108360.

47. Barreau F, Meinzer U, Chareyre F, Berrebi D, Niwa-Kawakita M, Dussaillant M, et al. CARD15/NOD2 is required for Peyer's patches homeostasis in mice. PLoS One. 2007;2(6), e523.

48. Ha SD, Park S, Han CY, Nguyen ML, Kim SO. Cellular adaptation to anthrax lethal toxin-induced mitochondrial cholesterol enrichment, hyperpolarization, and reactive oxygen species generation through downregulating MLN64 in macrophages. Mol Cell Biol. 2012;32(23):4846-60.
49. Svanborg Eden C, Hull R, Falkow S, Leffler H. Target cell specificity of wild-type E. coli and mutants and clones with genetically defined adhesins. Prog Food Nutr Sci. 1983;7(3-4):75-89.

50. Hashimoto M, Tawaratsumida K, Kariya H, Aoyama K, Tamura T, Suda Y. Lipoprotein is a predominant Toll-like receptor 2 ligand in Staphylococcus aureus cell wall components. Int Immunol. 2006;18(2):355-62.

51. Kao SJ, Lei HC, Kuo CT, Chang MS, Chen BC, Chang YC, et al. Lipoteichoic acid induces nuclear factor-kappaB activation and nitric oxide synthase expression via phosphatidylinositol 3-kinase, Akt, and p38 MAPK in RAW 264.7 macrophages. Immunology. 2005;115(3):366-74.

52. Schroder NW, Pfeil D, Opitz B, Michelsen KS, Amberger J, Zahringer U, et al. Activation of mitogen-activated protein kinases p42/44, p38, and stress-activated protein kinases in myelo-monocytic cells by Treponema lipoteichoic acid. J Biol Chem. 2001;276(13):9713-9.

53. Banerjee A, Gerondakis S. Coordinating TLR-activated signaling pathways in cells of the immune system. Immunol Cell Biol. 2007;85(6):420-4.

54. Gantner BN, Simmons RM, Canavera SJ, Akira S, Underhill DM. Collaborative induction of inflammatory responses by dectin-1 and Toll-like receptor 2 . J Exp Med. 2003;197(9):1107-17.

55. Kagan JC. Signaling organelles of the innate immune system. Cell. 2012;151(6):1168-78

56. Perea Velez M, Verhoeven TL, Draing C, Von Aulock S, Pfitzenmaier M, Geyer A, et al. Functional analysis of D-alanylation of lipoteichoic acid in the probiotic strain Lactobacillus rhamnosus GG. Appl Environ Microbiol. 2007;73(11):3595-604.

57. Travassos LH, Girardin SE, Philpott DJ, Blanot D, Nahori MA, Werts C, et al. Toll-like receptor 2-dependent bacterial sensing does not occur via peptidoglycan recognition. EMBO Rep. 2004;5(10):1000-6.

58. Inohara N, Ogura Y, Fontalba A, Gutierrez O, Pons F, Crespo J, et al. Host recognition of bacterial muramyl dipeptide mediated through NOD2. Implications for Crohn's disease. J Biol Chem. 2003;278(8):5509-12.

59. Chamaillard M, Girardin SE, Viala J, Philpott DJ. Nods, Nalps and Naip: intracellular regulators of bacterial-induced inflammation. Cell Microbiol. 2003;5(9):581-92.

60. Smits HH, Engering A, van der Kleij D, de Jong EC, Schipper K, van Capel $\mathrm{TM}$, et al. Selective probiotic bacteria induce IL-10-producing regulatory $T$ cells in vitro by modulating dendritic cell function through dendritic cellspecific intercellular adhesion molecule 3-grabbing nonintegrin. J Allergy Clin Immunol. 2005;115(6):1260-7.

61. van Hemert S, Meijerink M, Molenaar D, Bron PA, de Vos P, Kleerebezem M, et al. Identification of Lactobacillus plantarum genes modulating the cytokine response of human peripheral blood mononuclear cells. BMC Microbiol. 2010;10:293.

62. Lightfoot YL, Selle K, Yang T, Goh YJ, Sahay B, Zadeh M, et al. SIGNR3-dependent immune regulation by Lactobacillus acidophilus surface layer protein $A$ in colitis. EMBO J. 2015;34(7):881-95

63. Bermudez-Brito M, Munoz-Quezada S, Gomez-Llorente C, Matencio E, Bernal MJ, Romero F, et al. Cell-free culture supernatant of Bifidobacterium breve CNCM I-4035 decreases pro-inflammatory cytokines in human dendritic cells challenged with Salmonella typhi through TLR activation. PLoS One. 2013;8(3), e59370.

64. Bermudez-Brito M, Munoz-Quezada S, Gomez-Llorente C, Romero F, Gil A. Lactobacillus rhamnosus and its cell-free culture supernatant differentially modulate inflammatory biomarkers in Escherichia coli-challenged human dendritic cells. Br J Nutr. 2014;111(10):1727-37.

65. Messaoudi S, Manai M, Kergourlay G, Prevost H, Connil N, Chobert JM, et al. Lactobacillus salivarius: bacteriocin and probiotic activity. Food Microbiol. 2013;36(2):296-304.

66. Yue T, Pei J, Yuan Y. Purification and characterization of anti-Alicyclobacillus bacteriocin produced by Lactobacillus rhamnosus. J Food Prot. 2013;76(9):1575-81.

67. Li W, Yang S, Kim SO, Reid G, Challis JR, Bocking AD. LipopolysaccharideInduced Profiles of Cytokine, Chemokine, and Growth Factors Produced by Human Decidual Cells Are Altered by Lactobacillus rhamnosus GR-1 Supernatant. Reprod Sci. 2014;21(7):939-47.

68. Yang S, Li W, Challis JR, Reid G, Kim SO, Bocking AD. Probiotic Lactobacillus rhamnosus GR-1 supernatant prevents lipopolysaccharide-induced preterm birth and reduces inflammation in pregnant CD-1 mice. Am J Obstet Gynecol. 2014;211(1):44 e41-12.

69. Ono K, Han J. The p38 signal transduction pathway: activation and function. Cell Signal. 2000;12(1):1-13. 
70. Kim JS, Kim KD, Na HS, Jeong SY, Park HR, Kim S, et al. Tumor necrosis factor-alpha and interleukin-1 beta expression pathway induced by Streptococcus mutans in macrophage cell line RAW 264.7. Mol Oral Microbiol. 2012;27(3):149-59.

71. Shen J, Sakaida I, Uchida K, Terai S, Okita K. Leptin enhances TNF-alpha production via p38 and JNK MAPK in LPS-stimulated Kupffer cells. Life Sci. 2005;77(13):1502-15.

72. Kang JS, Yoon YD, Lee KH, Park SK, Kim HM. Costunolide inhibits interleukin-1 beta expression by down-regulation of AP-1 and MAPK activity in LPS-stimulated RAW 264.7 cells. Biochem Biophys Res Commun. 2004;313(1):171-7.

73. Wang H, Brown J, Martin M. Glycogen synthase kinase 3: a point of convergence for the host inflammatory response. Cytokine. 2011;53(2):130-40

74. Martin M, Rehani K, Jope RS, Michalek SM. Toll-like receptor-mediated cytokine production is differentially regulated by glycogen synthase kinase 3. Nat Immunol. 2005;6(8):777-84.

75. Bar-Yehuda S, Madi L, Barak D, Mittelman M, Ardon E, Ochaion A, et al. Agonists to the A3 adenosine receptor induce G-CSF production via NF-kappaB activation: a new class of myeloprotective agents. Exp Hematol. 2002;30(12):1390-8.

76. Wu MH, Lee YC, Tsai WJ, Yang WB, Chen YC, Chuang KA, et al. Characterized polysaccharides from black soybean induce granulocyte colony-stimulated factor gene expression in a phosphoinositide 3-kinase-dependent manner. Immunol Invest. 2010;40(1):39-61.

77. Chou YY, Gao Jl, Chang SF, Chang PY, Lu SC. Rapamycin inhibits lipopolysaccharide induction of granulocyte-colony stimulating factor and inducible nitric oxide synthase expression in macrophages by reducing the levels of octamer-binding factor-2. FEBS J. 2011;278(1):85-96.

78. Chou YY, Lu SC. Inhibition by rapamycin of the lipoteichoic acid-induced granulocyte-colony stimulating factor expression in mouse macrophages. Arch Biochem Biophys. 2011;508(1):110-9.

79. Petnicki-Ocwieja T, Kern A. Mechanisms of Borrelia burgdorferi internalization and intracellular innate immune signaling. Front Cell Infect Microbiol. 2015;4:175.

80. Cervantes IL, Dunham-Ems SM, La Vake CJ, Petzke MM, Sahay B, Sellati TJ, et al. Phagosomal signaling by Borrelia burgdorferi in human monocytes involves Toll-like receptor (TLR) 2 and TLR8 cooperativity and TLR8-mediated induction of IFN-beta. Proc Natl Acad Sci U S A. 2011;108(9):3683-8.

81. Moratalla A, Gomez-Hurtado I, Moya-Perez A, Zapater P, Peiro G, GonzalezNavajas JM, et al. Bifidobacterium pseudocatenulatum CECT7765 promotes a TLR2-dependent anti-inflammatory response in intestinal lymphocytes from mice with cirrhosis. Eur J Nutr. 2015.

82. Mohamadzadeh M, Olson S, Kalina WW, Ruthel G, Demmin GL, Warfield KL, et al. Lactobacilli activate human dendritic cells that skew T cells toward T helper 1 polarization. Proc Natl Acad Sci U S A. 2005;102(8):2880-5.

83. Saber R, Zadeh M, Pakanati KC, Bere P, Klaenhammer T, Mohamadzadeh M Lipoteichoic acid-deficient Lactobacillus acidophilus regulates downstream signals. Immunotherapy. 2011;3(3):337-47.

84. Carulli G. Effects of recombinant human granulocyte colony-stimulating factor administration on neutrophil phenotype and functions. Haematologica. 1997;82(5):606-16.

85. Bober LA, Grace MJ, Pugliese-Sivo C, Rojas-Triana A, Waters T, Sullivan LM, et al. The effect of GM-CSF and G-CSF on human neutrophil function. Immunopharmacology. 1995;29(2):111-9.

86. Weiss M, Gross-Weege W, Schneider M, Neidhardt H, Liebert S, Mirow N, et al. Enhancement of neutrophil function by in vivo filgrastim treatment for prophylaxis of sepsis in surgical intensive care patients. J Crit Care. 1995;10(1):21-6

87. Meshkibaf S, William Gower M, Dekaban GA, Ouk Kim S. G-CSF preferentially supports the generation of gut-homing Gr-1high macrophages in M-CSF-treated bone marrow cells. J Leukoc Biol. 2014;96(4):549-61.

88. Rutella S, Bonanno G, Pierelli L, Mariotti A, Capoluongo E, Contemi AM, et al. Granulocyte colony-stimulating factor promotes the generation of regulatory DC through induction of IL-10 and IFN-alpha. Eur J Immunol. 2004;34(5):1291-302.

89. Rutella S, Danese S, Leone G. Tolerogenic dendritic cells: cytokine modulation comes of age. Blood. 2006;108(5):1435-40.

90. Rutella S, Zavala F, Danese S, Kared H, Leone G. Granulocyte colonystimulating factor: a novel mediator of T cell tolerance. J Immunol. 2005;175(11):7085-91.
91. Gan XT, Ettinger G, Huang CX, Burton JP, Haist JV, Rajapurohitam V, et al. Probiotic administration attenuates myocardial hypertrophy and heart failure after myocardial infarction in the rat. Circ Heart Fail. 2014;7(3):491-9.

92. Lam V, Su J, Koprowski S, Hsu A, Tweddell JS, Rafiee P, et al. Intestinal microbiota determine severity of myocardial infarction in rats. FASEB J. 2012;26(4):1727-35.

93. Roberts AW. G-CSF: a key regulator of neutrophil production, but that's not all! Growth Factors. 2005;23(1):33-41.

94. Shimoji K, Yuasa S, Onizuka T, Hattori F, Tanaka T, Hara M, et al. G-CSF promotes the proliferation of developing cardiomyocytes in vivo and in derivation from ESCs and iPSCs. Cell Stem Cell. 2010;6(3):227-37.

95. Solaroglu I, Cahill J, Tsubokawa T, Beskonakli E, Zhang JH. Granulocyte colony-stimulating factor protects the brain against experimental stroke via inhibition of apoptosis and inflammation. Neurol Res. 2009;31(2):167-72.

\section{Submit your next manuscript to BioMed Central and take full advantage of:}

- Convenient online submission

- Thorough peer review

- No space constraints or color figure charges

- Immediate publication on acceptance

- Inclusion in PubMed, CAS, Scopus and Google Scholar

- Research which is freely available for redistribution 